\title{
Setting an Arctic Course: Task Force 80 and Canadian Control in the Arctic, 1948 $^{1}$
}

\section{Peter Kikkert and P. Whitney Lackenbauer}

\begin{abstract}
Utilisant pour cette étude le cas de la Force opérationnelle 80 et la mission de réapprovisionnement dans le grand nord de 1948, les auteurs examinent de façon critique les relations Canadien-Américaines dans l'Arctique au début de la guerre froide. Les données archivistiques indiquent que, plutôt que de sacrifier la souveraineté dans l'intérêt de la sécurité continentale, le gouvernement canadien a scruté et a surveillé les activités de défense américaines dans l'Arctique pour s'assurer qu'il maintienne un niveau de contrôle approprié. Il y avait des inadvertances, des caprices et des malentendus de part et d'autre, mais les officiels ont compris des leçons importantes de la mission de 1948 qui ont été appliquées aux activités ultérieures de réapprovisionnement, prenant le cap vers un rapport opérationnel de plus en plus fonctionnel.
\end{abstract}

On the afternoon of 30 July 1948, the icebreakers United States Ship (USS) Edisto and United States Coast Guard Ship (USCG) Eastwind left the anchorage at Thule, Greenland and set a course for the coast of Ellesmere Island. Along with a third vessel, the cargo ship USS Wyandot, which was on its way to Resolute Bay, the little group was called Task Force 80. Its mission seemed straightforward: resupply the joint Arctic weather stations set up the previous summer and establish a new one on the northern tip of Ellesmere. ${ }^{2}$ The voyage, however, proved anything but simple.

By the next morning the ships were cautiously picking their way through loose and scattered floe ice. Their helicopters scouted for the best routes, but by evening the two icebreakers ran into thick pack ice as they neared central Kane Basin. Their progress

1 Thanks to Daniel Heidt for sharing research material and for commenting on an earlier draft of this article. This research was supported by SSHRC graduate fellowships, a Fulbright fellowship at the School for Advanced International Studies at Johns Hopkins University in Washington, D.C., a St. Jerome's University internal faculty research grant, and an ArcticNet grant on the evolving Arctic security environment.

2 Edisto and Eastwind were two of seven ships built for the U.S. government at San Pedro, California by Western Pipe and Steel Company, which became known as the Northwind Class. Edisto and Burton Island were operated by the USN, and Northwind and Eastwind by the USCG. Captain F.A. Germain, DOT, to J.C. Lessard, Deputy Minister, 29 April 1949, Library and Archives Canada (hereafter "LAC"), Record Group (RG) 25, vol. 5737, file 17-E (s).

The Northern Mariner/le marin du nord, XXI No. 4, (October 2011), 327-358 
slowed considerably. A heavy fog rolled in before they could find leads in the ice, effectively grounding the helicopters. Without eyes in the sky, it was impossible to safely navigate and Edisto hove to until the following morning. It still managed to travel further north than Eastwind, which had damaged its bow propeller. In the morning, Edisto's helicopters took off once again and guided the ships to leads and the easiest routes through the ice.

On 1 August, the ship once again made significant headway, ramming its way through looser pack ice in the approaches to Robeson Channel. This progress was short lived. The icebreaker hit the heaviest ice yet as it bucked its way toward Cape Sheridan. By the next day its hull was badly dented in several places - fortunately there were no leaks. Far worse, Edisto lost its entire port screw and a portion of the shaft, which could have spelled disaster. Still the icebreaker churned forward through the ice, inching its way further north. Damage and all, it reached $82^{\circ} 34 \mathrm{~N}$ - further north than any previous vessel - before anchoring in Dumbbell Bay and unloading its cargo at what is now Alert. ${ }^{3}$ Maritime history had been made.

On 8 August 1948, Tom Weir, a Canadian observer on Edisto and a civil servant with the Department of Mines and Resources, informed his boss Trevor Lloyd that the icebreaker had set a new furthest north. "It is really atomic isn't it?" Weir noted. The fact that an American ship had done it upped the ante for Canada, but it called for celebration in Weir's eyes. "It is really something to do for Canadians in the near future," he exclaimed, "and it is in my opinion good news for Dr. Keenleyside and for you in their efforts to get full support of [the] Canadian Government for Arctic projects." 4

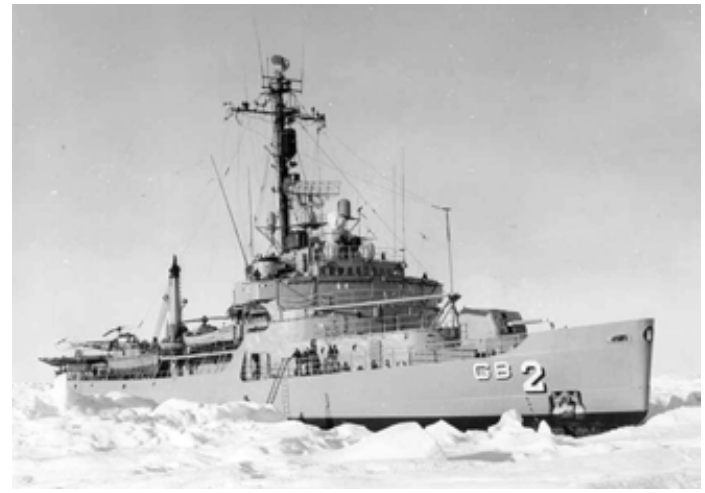

Illustration 1: The icebreaker USS Edisto (AG-89) was launched in May 1946 and delivered to the US Navy in March 1947. Photo: US Coast Guard.

Few officials in the Canadian government would have used "atomic" to describe the accomplishment. Edisto's success caused a great deal of consternation in Ottawa, where officials had struggled since the end of the Second World War to constrain their continental neighbour and ally from encroaching upon or challenging Canada's Arctic sovereignty. Despite repeated American assurances that they harboured no sinister plans to undermine Canadian sovereignty over the Arctic archipelago, the United States refused - for longstanding legal reasons - to formally recognize Canada's sector claims. On 16

3 Report of Arctic Summer Operation, 1948, U.S. Navy Task Force Eighty, U.S. Atlantic Fleet, LAC, RG 85, vol. 2088, file CR 19; George Dufek to United States Atlantic Fleet, 7 August 1948, Syracuse University Library, Special Collections Research Center, George Dufek Papers (hereafter "Dufek Papers"), Task Force 80 Box 1, Correspondence 1948. 
January 1947, after months of careful negotiations, the two countries finally agreed on Recommendation 36 of the Permanent Joint Board on Defence, a paper agreement that guaranteed Canada's de jure (legal) sovereignty in the North. ${ }^{5}$ Senior civil servants in Ottawa, however, believed that such paper guarantees were useless unless the government could actually control activities in its jurisdiction. Edisto's success highlighted Canada's inability to operate independently in the region, let alone control activities within it. The Americans, by contrast, were using their icebreakers effectively in the Canadian Arctic, learning a great deal about the region and how to operate in it and, perhaps worst of all, were breaking records.

The historiography on Canadian-American relations and the Arctic sovereigntysecurity balance in the early Cold War largely falls into two general camps. In 1989, Shelagh Grant's Sovereignty or Security? alleged that Canada sacrificed control (and thus sovereignty) to meet American continental defence needs. ${ }^{6}$ American paper guarantees held little weight in practice, she alleged, and the ever-conniving Americans continuously violated Canadian laws and control in their quest for security. Even worse, the Canadian government allowed them to do it. ${ }^{7}$ Historian Adam Lajeunesse has recently concurred with Grant's assertion that Canada's unwillingness to invest in Arctic defences, coupled with the sheer dominance of the Americans on the ground, undermined Canada's control. ${ }^{8}$ In the opposing camp, historians David Bercuson, Elizabeth Elliot-Meisel, and others have emphasized the cooperation, respect, and open dialogue that characterized the defence relationship after 1946, and argue that Ottawa successfully safeguarded Canada's sovereignty and effectively contributed to continental security. ${ }^{9}$

5 David Bercuson, "Continental Defense and Arctic Security, 1945-50: Solving the Canadian Dilemma," in The Cold War and Defense, K. Neilson and R.G. Haycock, eds. (New York, 1990), 161. At the time, the Permanent Joint Board on Defence was the senior bilateral defence agency between Canada and the United States. Created at Ogdensburg in 1940, the board continued to play an important role in the early Cold War.

6 Shelagh Grant, Sovereignty or Security? Government Policy in the Canadian North, 19361950 (Vancouver, 1988).

7 Grant, Sovereignty or Security, 241, 243. Although less overtly suspicious of American intentions and critical of the Canadian government, Grant's recent study Polar Imperative (Vancouver, 2010) neither forwards nor retracts the conclusions she reached in her earlier work.

8 Adam Lajeunesse, “The True North As Long As It's Free: The Canadian Policy Deficit 19451985" (unpublished M.A. thesis, University of Calgary, 2007), 25.

9 Bercuson, "Continental Defence and Arctic Sovereignty," 153-70; Elizabeth Elliot-Meisel, Arctic Diplomacy: Canada and the United States in the Northwest Passage (New York, 1998); Whitney Lackenbauer, "Right and Honourable: Mackenzie King, Canadian-American Bilateral Relations, and Canadian Sovereignty in the Northwest, 1943-1948," in Mackenzie King: Citizenship and Community, J. English, K. McLaughlin and W. Lackenbauer, eds. (Toronto, 2002), 151-68; and P. Whitney and Peter Kikkert, "Sovereignty and Security: The Department of External Affairs, the United States, and Arctic Sovereignty, 1945-68," in In the National Interest: Canadian Foreign Policy and the Department of Foreign Affairs and International Trade, 1909-2009, Greg Donaghy and Michael Carroll, eds. (Calgary, 2011), 101-20. 
The story of Task Force 80 and its aftermath reinforces the idea that the Canadian government did not waver in its concern for the Arctic in the early postwar era. It did not hand the Americans the keys to the Arctic and simply turn a blind eye to events on the ground. Although the Americans were attentive to Canada's concerns and offered solid assurances protecting Canada's Arctic claims during defence negotiations in late 1946 and early 1947, Canadian officials feared that their counterparts' sensitivity would fade. As the case study of Task Force 80 and the resupply mission of 1948 highlights, the Canadian government crafted agreements on individual defence projects and continued to monitor all American activities in the region to ensure an appropriate level of control. While Canada relied on acts of "symbolic sovereignty"10 during Task Force 80 and other American-dominated operations, senior officials also realized the functional capabilities required for Ottawa to sustain control in the region.

Officials also learned how to deal with Americans' intransigence and their occasionally domineering approach. Whenever a defence project strayed from its approved guidelines, Canadian officials registered their complaints and asked the Americans to rectify the situation. Their southern counterparts usually complied. While some low-ranking American officers questioned Canada's authority, most senior officials complied with it, took action to address indiscretions, and resolved Canadian concerns. The U.S. desire to secure the Canadians as faithful allies in continental security — which was of primary importance — encouraged them to respect Canada's sovereignty. Accordingly, controversies surrounding Task Force 80 should not be misread as evidence of pernicious American intent. There were oversights, missteps, and miscommunication on both sides, but officials derived important lessons from the 1948 mission which were applied to subsequent resupply activities, facilitating a smoother operational relationship in the years ahead.

\section{Controlling the Arctic}

For Canadians the Second World War renewed concerns about terrestrial sovereignty in the Arctic. The Japanese attack on Pearl Harbor on 7 December 1941 heightened the importance of the Canadian Northwest as a strategic link to Alaska. Accordingly, the United States launched massive defence projects in northern Canada, including the Northwest Staging Route airfields, the Canol pipeline, and the Alaska Highway. Although Prime Minister William Lyon Mackenzie King allowed the Americans onto Canadian soil with few constraints, he was always suspicious of their intentions. Worrisome reports from Malcolm MacDonald, the British high commissioner who visited the defence projects in 1943 and was alarmed at the scale of American activities, spurred the prime minister to reassert control in the Canadian North. To ensure greater control over American activities and protect Canadian sovereignty, the government appointed special commissioner Brigadier W.W. Foster to oversee the various American defence projects in the Northwest. As the war drew to a close, Canada

10 On this concept, see William R. Morrison, "Eagle Over the Arctic: Americans in the Canadian North, 1867-1985," Canadian Review of American Studies XVIII, no.1 (Spring 1987), 61-85. 
secured full ownership of all permanent facilities on its territory by purchasing them from the United States. The Americans also agreed that, prior to initiating any project on or over Canadian territory, they needed the Canadian government's approval. ${ }^{11}$

During early Cold War defence negotiations, Canadian diplomats remained both attentive and responsive to potential sovereignty encroachments. When the wartime relationship between the Western allies and the Soviet Union quickly dissolved, Canada recognized its undesirable strategic position sandwiched between two opposing superpowers. "Canada could not stay out of a third World War if 11,999,999 of her 12,000,000 citizens wanted to remain neutral," Minister of External Affairs Louis St. Laurent quipped. ${ }^{12} \mathrm{He}$ had a point. Canada had become the potential frontline of the next global conflict. "The dilemma," Bercuson has argued, was simple: "how could Canada help protect the continent against the Soviet Union - a job Ottawa agreed needed doing while, at the same time, it protected the Canadian north against the United States?"13

In early May 1946 the United States proposed the establishment of a chain of weather stations in the Canadian Arctic, which would assist with advanced forecasting and be essential for future military operations. ${ }^{14}$ Despite American assurances that Canada's sovereignty would not be threatened, Canadian officials believed that American acceptance of the sector principle - which allotted to Canada a slice of the Arctic between $60^{\circ} \mathrm{W}$ to $141^{\circ} \mathrm{W}$ up to the North Pole - was the simplest way to protect their national interests. ${ }^{15}$ The Americans refused to acquiesce, however, because it would have

11 Stanley Dziuban, Military Relations Between the United States and Canada 1939-1945 (Washington, 1959), 138. Several scholars have speculated that the U.S. Government had a diabolical agenda for the Canadian North during the war. See, for example, Grant, Sovereignty or Security, 185; Donald Creighton, The Forked Road: Canada 1939-1957 (Toronto, 1976), 74. The American response to these Canadian initiatives, if one avoids the lure of the "conspiratorial view" of history, was not a cause for concern but cautious optimism. They were actually encouraged by the involvement of Brigadier Foster in defence planning. For this view, see Lackenbauer, "Right and Honourable," 154.

12 Bernd Horn, "Gateway to Invasion or the Curse of Geography? The Canadian Arctic and the Question of Security, 1939-1999," in Forging a Nation: Perspectives on the Canadian Military Experience, ed. Bernd Horn (St. Catharines, 2002), 318.

13 Bercuson, "Continental Defence and Arctic Sovereignty," 155.

14 On the Joint Arctic Weather Stations, see Gordon W. Smith, "Weather Stations in the Canadian North and Sovereignty," Journal of Military and Strategic Studies XI, no.3 (Spring 2009) and Daniel Heidt, "Clenched in the JAWS of America: Canadian Sovereignty and the Joint Arctic Weather Stations, 1946-1972," in Canada and Arctic Sovereignty and Security: Historical Perspectives, ed. P.W. Lackenbauer (Calgary, 2011), 145-70.

15 Memorandum from Head, Third Political Division Legal Division, 1 January 1946, in Documents on Canadian External Relations (hereafter DCER), vol. 12, 1946, ed. Donald Page (Ottawa, 1977); L.B Pearson to H.H. Wrong, 18 June 1946, LAC, RG 25, accession 1986-87/159, box 41, file 9057-C-40, pt. 4. As Gordon W. Smith explained, the sector principle held that "each state with a continental Arctic coastline automatically falls heir to all islands lying between this coastline and the North Pole, which are enclosed by longitudinal lines drawn from the eastern and western extremities of the same coastline to the Pole." Canadian officials relied ambiguously on this principle to support their claims in the 
set a precedent elsewhere: the Soviet Union claimed a large section of the Arctic and several nations claimed vast portions of the Antarctic on these grounds. Accepting Canada's claims would have strengthened the positions of these nations to the detriment of Washington's strategic interests. ${ }^{16}$ Canadian officials who acknowledged this reality set to work creating guidelines for a joint Arctic weather programme that would support Canada's claims. The key provisions - that Canada retained permanent rights to any installations, the majority of personnel were Canadian, and the projects would be under Canadian command ${ }^{17}$ - reflected lessons learned during the final years of the war.

Though the Americans pressured the Canadians for a quick decision, King denied the American request for that year. Acknowledging the American tendency to act swiftly and with little concern for Canada's needs when threatened, the prime minister hoped this would force the United States to pause and evaluate Canada's difficult position. On 2 July 1946, Ottawa informed Washington that the programme had not been rejected - only deferred for the purposes of further study. ${ }^{18}$ This prime ministerial-directed policy of delaying decisions on continental defence, slowing the whole process until the complex situation could be sorted out beneficially for Canada, was cautious but prudent. Bold, aggressive moves (particularly ones that would have entailed significant Canadian defence expenditures) would have been out of step with the cooperative defence relationship then taking shape. ${ }^{19}$ In the meantime, the Canadians allowed the Americans to conduct small scale, temporary operations in parts of the Arctic, as long as they seemed to pose no threat to Canada's sovereignty.

In early 1947, after careful negotiations, the two countries accepted a set of formal guidelines regulating continental defence that reinforced the idea that the U.S. had

Arctic, despite its dubious veracity in international law. See "Sovereignty in the North: The Canadian Aspect of an International Problem," in The Arctic Frontier, ed. R.St.J. Macdonald (Toronto, 1966), 214.

16 A close contemporary parallel to this is the position of the United States on the Northwest Passage. If the Americans accept Canada's position on the passage and allow it to be treated as Canadian internal waters, this would set a precedent for more strategically important straits throughout the world. Accordingly, strategic and political implications make it unlikely that the U.S. will accept the Northwest Passage as Canadian internal waters, just as similar considerations kept the U.S. from accepting the sector principle in 1946. See Ken Coates, Whitney Lackenbauer, William Morrison, and Greg Poelzer, Arctic Front: Defending Canada in the Far North (Toronto, 2008), 83.

17 Memorandum for Cabinet Defence Committee, "United States proposals for an Arctic Weather Station Programme," from External Affairs, 30 May 1946, LAC, RG 25, vol. 3346, file 9061-A-40C, pt.1.

18 "Memorandum - United States Proposals for Weather Stations in the Arctic," 4 July 1946, ibid.

19 On this era see Joseph T. Jockel, "The Canada-United States Military Co-operation Committee and Continental Air Defence, 1946," Canadian Historical Review LXIV, no.3 (1983), 352-77; and David Bercuson, True Patriot: The Life of Brooke Claxton, 1898-1960 (Toronto, 1993), 153-74. 
no desire to violate Canadian sovereignty. ${ }^{20}$ "As an underlying principle," King explained in the House of Commons, "all cooperative arrangements will be without impairment of the control of either country over all activities in its territory." ${ }^{21}$ Canada had explicit assurance that its terrestrial sovereignty in the Arctic would not be challenged, but the government still decided to carefully monitor all American activities in the region to maintain some level of Canadian control. ${ }^{22}$

With a bilateral defence cooperation agreement firmly in place, the United States was authorized to implement its plans for a system of joint weather stations in the Arctic. In the summer of 1947, a U.S. Navy task force, supported by airlifts from the United States Army Air Forces, established two stations in the Canadian Archipelago: at Resolute Bay on Cornwallis Island and Slidre Bay on Ellesmere Island. The next spring two more stations were set up at Deer Bay on the Isachsen Peninsula, Ellef Ringnes Island and at Mould Bay, Prince Patrick Island. These isolated stations were completely dependent on aerial and naval resupply. ${ }^{23}$ Canada, however, had few aircraft and no naval ships capable of providing the support required by the stations. The Americans would have to provide the lifeline to the weather stations, an idea that did not sit well with Canadian officials. Nightmares of American flags flying throughout the Arctic, with hundreds of U.S. servicemen flooding into the region to challenge Canada's control, gravely concerned Ottawa, even with the freshly signed paper guarantees on the prime minister's desk. A major investment in Canada's Arctic capabilities might allay anxieties, but when it came to actual resource allocation the Liberal government was broadly dedicated, in Mackenzie King's words, to "the old Liberal principles of economy, reduction of taxation, anti-militarism, etc." ${ }^{24}$ For all its rhetorical concern with sovereignty and security, it was in no hurry to commit to costly initiatives.

20 Bercuson, "Continental Defence and Arctic Sovereignty," 161. By March 1947 the Cabinet approved the construction of the Joint Arctic Weather Stations and three Long Range Aid to Navigation (LORAN) posts. Although External Affairs has been praised for its use of the functional principle in international politics, it also applied the principle to the new defence projects in the North, insisting that as soon as qualified Canadian personnel could be trained they would replace the Americans. L.B. Pearson to Ray Atherton, 22 December 1947, and D.M Johnson to Mr Rae, 25 April 1947, LAC, RG 25, vol. 3841, file 9061-A-40, pt.2. Eventually functionalism was also applied to Arctic re-supply missions, with Canadians gradually assuming more responsibility for northern airlifts and building an icebreaker to assist in naval expeditions. On the concept of functionalism, see A.J. Miller, "The Functional Principle in Canada's External Relations," International Journal XXXV, no.2 (1980): 30928.

21 House of Commons, Debates, 12 February 1947.

22 See, for example, Peter Kikkert, "The Polaris Incident: 'Going to the Mat' with the Americans," Journal of Military and Strategic Studies XI, no.3 (2009), 1-29.

23 Meteorological Division, Department of Transport-Canada, and U.S. Weather Bureau,Department of Commerce, United States, A Review of the Establishment and Operation of the JAWS at Eureka Sound, Resolute, Isachsen, Mould Bay and Alert and a Summary of the Scientific Activities at the Stations, 1946-1951 (Ottawa, 1951).

24 J.W. Pickersgill and D.F. Forster, The Mackenzie King Record, vol. IV (Toronto, 1960), 6. 
Canadian officials (particularly in the Department of Mines and Resources and the Northwest Territories Administration) pondered how Canada could best maintain its control of developments in the Arctic without spending millions of dollars. ${ }^{25}$ In March 1947, David M. Johnson informed the U.S. Embassy of the rules and regulations all American personnel involved in Arctic operations, including those on short term resupply missions, would be expected to follow. The Game Laws of the Arctic Preserve forbade all but the Inuit from hunting in the Arctic Game Preserve and insisted that no autoloading rifles or automatic pistols be taken into the territories. The Archaeological Sites Ordinance of the Northwest Territories Administration held that no site could be excavated or relics taken from the territories without a license from the territorial commissioner. Finally, the Scientists and Explorers Ordinance stipulated that any scientists attached to Arctic operations needed special permission from the commissioner and had to make available all of their research. ${ }^{26}$ Perhaps most importantly, Ottawa insisted that Canadian observers accompany all American missions and projects in the North to serve as the government's "eyes" on the ground. ${ }^{27}$ Canadian officials believed these rules would allow them to maintain a semblance of practical control.

By all accounts, the large scale USN task force that ventured into Arctic waters in the summer of 1947 to establish the first joint weather stations ran smoothly and without major incident. The Americans followed Canadian guidelines carefully and granted Canadian observers a great deal of access to operational and scientific material. Nevertheless, the Canadian government remained worried about its ability to exercise control over American-dominated activities.

25 Wright to Gibson, 29 November 1946, LAC, RG 85, vol. 823, file 7140; Deputy Minister of Mines and Resources to the Acting Under-Secretary of State for External Affairs (USSEA), R.M MacDonnell, 20 December 1946, LAC, RG 25, vol. 3347, file 9061-A-40C; Wardle to Jackson 19 December 1946, LAC, RG 88, vol. 19, file SE. 4-1-83.

26 D.M. Johnson to Mr. Dow, 11 March 1947, LAC, RG 25, vol. 3841, file 9061-A-40, pt. 2.

27 For example, three observers joined Operation Nanook, an American naval expedition to the waters of Davis Strait, Viscount Melville Sound and Lancaster Sound, in the summer of 1946. Relations remained generally positive between the observers and American personnel on the cruise, which accomplished most of its objectives and adhered carefully to Canadian guidelines. Canadian Ambassador Washington to SSEA, No. WA-3686, 16 October 1946, sending message for Macdonnell from Stone, LAC, RG 25, vol. 3347, file 9061-B-40. Nevertheless, the observers noted the unwillingness of low-ranking American military personnel to cooperate with the Canadians. Lt. W.E. Widdows revealed that "the Observers were treated with courtesy, but on the whole it was felt that they were considered merely as passengers. Information was never volunteered, and when given as a result of a direct question, seemed to be with reluctance." Widdows to Captain R.E.S. Bidwell, 11 October 1946, LAC, RG 24, vol. 8152, file NSS 1660-12, pt.1. Another observer, Lt. Dunn Lantier, complained that the Americans often refused to discuss operational matters with the observers and even forbade the Canadians from entering the navigation bridge. The Canadians were left feeling that the Americans considered them to be "very much in the way." Lantier to Captain H.N Lay, 3 October 1946, LAC, RG 24, vol. 8152, file NSS 166012, pt.1. 


\section{A Canadian Maritime Capability?}

The most obvious solution to the problem of control was to invest in Canadian maritime capabilities so that Canada could transport materials in its own Arctic. Since 1946, the RCN had pondered the possibility of creating a Canadian presence in the region. That year the Americans completed Operation Nanook, a large scale naval expedition to the eastern approaches of the Northwest Passage. In response, a Canadian internal report speculated on the possible commercial promise of the Passage and admitted that no Canadian naval ship had ever entered Arctic waters, leaving the RCN officer cadre with no Arctic experience. However remote the possibility of a naval engagement in these areas, the report encouraged the RCN to correct this "complete lack" of experience. ${ }^{28}$

Historian Elizabeth Elliot-Meisel has ably documented the RCN's postwar Arctic plans and its struggle to put them into effect. In April 1947, planners considered a cruise to Hudson Strait and Hudson Bay so that the RCN could explore the problems and conditions of Arctic sea travel on its own. Without ice-capable ships, and with a "drastic curtailment" in RCN fuel supplies, the government scuttled these plans, but concerns persisted about Canada's Arctic transportation capabilities. Minister of National Defence Brooke Claxton announced the immediate winterization of the Tribal class destroyers and of HMCS Magnificent, Canada's aircraft carrier, in July 1947, and the Chiefs of Staff Committee noted a few months later that "adequate transportation facilities, both air and sea, must also be provided and controlled by Canada if over-all control is to be maintained." 29 The Cabinet Defence Committee echoed these concerns. ${ }^{30}$ Rhetorical resolve was not action, however, and priorities still lay elsewhere. The Chief of the Naval Staff argued that it was too early to develop dedicated Arctic units "because of the continuing RCN responsibility for protecting vital lines of communication in coastal waters and possibly further afield." ${ }^{31}$ Anti-submarine duties in the North Atlantic and a shrinking budget precluded the Navy from embarking on large-scale Arctic activities.

The Department of National Defence and the Cabinet Defence Committee, however, continued to focus on the North and began to contemplate the construction of a naval icebreaker, modelled after the American Edisto or Northwind class, to assist in northern supply cruises. ${ }^{32}$ The Advisory Committee on Northern Development, at its

28 Memorandum to ACNS and CNP from P.T.O., Reference - PJBD American Section Letters of 14 May 1946 and 22 May 1946, ibid.

29 Elliot-Meisel, "The Royal Canadian Navy in Arctic Waters," 28-30; House of Commons Debates, 9 July 1947, 5270. The winterization of these vessels would not allow them to truly operate in the ice filled northern waters, however, save for a brief period in the summer (and then only in select areas). Acquiring a true northern naval capability required more resources.

30 Memorandum to Cabinet Defence Committee: Arctic Air Facilities - Resolute Bay, DHH 112.009 (D44).

31 Extract from Minutes of Meeting of Cabinet Defence Committee, 8 January 1948, DCER, vol. 14, 1948, ed. Hector Mackenzie (Ottawa, 1994), 1532. 
second meeting held just days before Task Force 80 set out for the Arctic, placed a high priority on the government's acquisition of a set of icebreakers to support its efforts "in maintaining control over Canadian Arctic areas and supporting claims for sovereignty, of being in a position to provide access to these areas independently of the U.S." ${ }^{33}$ Steel shortages, however, meant practical delays in ship construction. ${ }^{34}$ Accordingly, the U.S. would continue to shoulder the burden in the Arctic.

\section{Planning Task Force 80}

As the Canadians began drawing out their plans to construct a pair of icebreakers, the Americans tackled the problem of how to supply the joint weather stations in the high Arctic. The planning meetings for the 1948 naval mission commenced in Washington on 1 April and were attended by members of Canada's joint staff. The basic purpose of Task Force 80 was to resupply the weather stations at Thule, Resolute, Slidre Bay, Deer Bay and Mould Bay and to land the necessary construction materials for additional stations at Winter Harbour on Melville Island and on the northeast coast of Ellesmere Island. ${ }^{35}$ The secondary tasks included icebreaker reconnaissance in areas where future stations might be built, personnel training, testing ships and material in Arctic conditions, geographical and navigational observations, recording detailed hydrographic, meteorological and electro-magnetic propagation data, and other sundry scientific projects. The Americans hoped to improve their ability to navigate in the Arctic and resolve ice issues, unreliable charts, compass errors and the lack of celestial fixes. ${ }^{36}$ Besides the ships, the Task Force included two specifically adapted RG-17G aircraft from the $311^{\text {th }}$ Air Division, 55 Reconnaissance Group. The planes, based out of Thule, Resolute Bay and Frobisher Bay, would provide long range ice reconnaissance for the Navy. The whole Task Force consisted of some 700 men.

The task force commander, Captain George Dufek, had extensive experience in the polar regions. A naval aviator and navigator of the USS Bear, the flagship of Rear Admiral Richard E. Byrd's third expedition to Antarctica during the interwar years, he received the Antarctic Expedition Medal for his exploratory flying. During the Second World War, he commanded a flight training squadron, was senior naval aviator in Algeria during the invasion of North Africa, and helped plan the invasions of Sicily, Salerno and southern France. Promoted to captain, he assumed command of the escort aircraft carrier

\section{Defence, 2 February 1948, LAC, RG 2, vol. 56, file A-25-1.}

33 Extract from Minutes of Second Meeting of Advisory Committee on Northern Development (ACND), 1 June 1948, DCER, vol. 14, 1948, 1523. On the ACND, see Grant, Sovereignty or Security, 223-228.

35 Report of Arctic Summer Operation, 1948, U.S. Navy Task Force 80, U.S. Atlantic Fleet, NARA, RG 218, entry 7, box 4, B.P CCS 381, (10-1-46), file Report of Arctic Summer Op, 1948; Office of the Chief of Naval Operation, Navy Task Force to Resupply Weather Stations, 27 May 1948, LAC, RG 25, vol. 3841, file 9061-G-40.

36 Report of Arctic Summer Operation, 1948, U.S. Navy Task Force 80; Operational Plan, Task Force Eighty, 15 June 1948, LAC, RG 85, vol. 2084, file 16477. 
USS Bogue, whose aircraft and escorts sank the final German U-boat during the war. After a short postwar assignment in Japan, Dufek returned to the polar regions as a commander on Operation Nanook. He then served with Operation Highjump, another naval expedition to Antarctica under the command of Admiral Byrd, and completed the first flight over the Thurston Peninsula. When he returned to Washington, D.C., his polar experience made him a logical fit to command Task Force $80 .{ }^{37}$ Dufek soon realized, however, that the mission called for far more than the ability to operate effectively in Arctic conditions. He would also have to navigate through difficult political issues.

As planning for the mission progressed, Dufek and his staff carefully considered Canadian sensitivities. The operational plan noted the difficulties that defence operations created for the Canadian government, given the serious division that still existed inthe government and the public about Canada's participation in continental defence. $^{38}$ The most pressing concerns revolved around the questions of sovereignty, control, and publicity. Although the Americans understood "these issues [and], after numerous difficulties and altercations, finally have found effective answers through the efforts of the Permanent Joint Board on Defense, Canada-United States," they still had to be careful "to insure that small oversights do not occur to mar present friendly relations." 39

Planning documents reflected the spirit of cooperation and accommodation

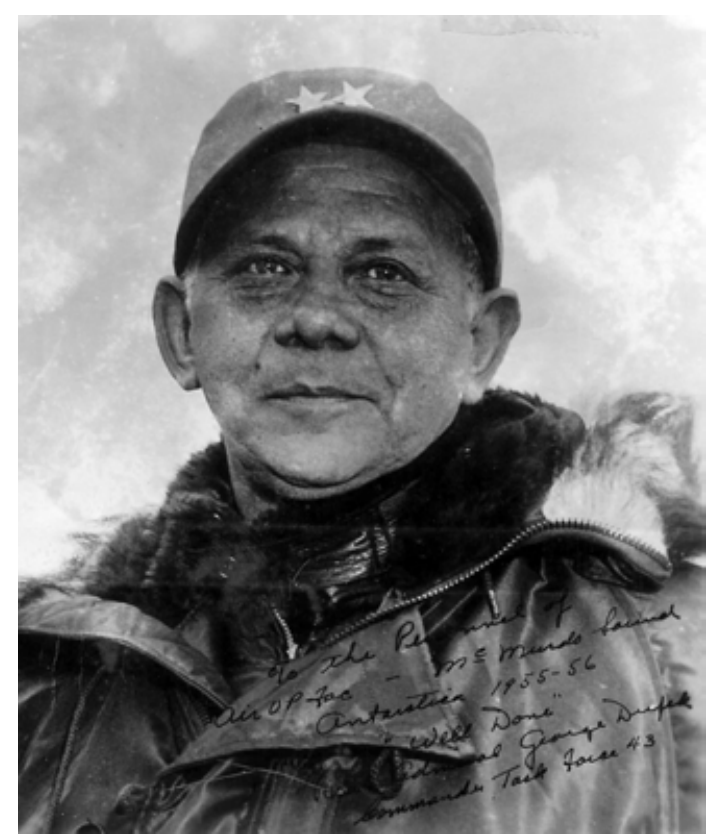

Illustration 2: George J. Dufek, the renowned naval aviator and polar expert, as a rear admiral in the US Navy in 1955. Photo: National Science Foundation. between the two countries. The operational plan for the mission noted the speech given by Louis St. Laurent on 29 April 1948, which set the tenor for the broader continental relationship. "One source of whatever difficulties we have with our good neighbour is a flattering, if at times trifle embarrassing, tendency on their part to consider us so much as one of themselves that, with the best intentions, they occasionally forget we are as sensitive as any nation about having control over our own affairs," St. Laurent noted.

37 Dufek Papers. Finding aid online at http://library.syr.edu/digital/guides/d/dufek_gj.htm.

38 Report of Arctic Summer Op. 19482 - US Atlantic Commander Task Force, Arctic Operation Summer 1948, Operation Plan No. 1-48, 16 June 1948, NARA, RG 218, entry 7, box 4. The report highlighted the divisions within the Canadian Cabinet, particularly between St. Laurent and Claxton over defence matters. Ibid. 
Nevertheless, American defence activities did not threaten Canadian control, given that the U.S. accepted the 1947 defence cooperation agreement. The operational plan cited the various Canadian regulations that the USN was obliged to follow during the mission, and at the highest level the Americans were prepared to show the utmost respect to the conditions and rules set for their activities in the Arctic. ${ }^{40}$

Despite this message of cooperation, Canadian officials also recognized the need for vigilance when it came to actual American naval activities. The two previous cruises to the Canadian Arctic had generated few complaints, but federal officials knew that Canada had not regulated the operations as extensively as it could have. For instance, the Canadians never asked the Americans to disclose the routes they would take or to provide information on additional scientific studies they performed. This changed in 1948. In March, George Magann, a counsellor at the Canadian embassy in Washington, suggested the government should demand an outline of all activities associated with Task Force 80. The government subsequently required a "full picture" of what would happen during the expedition "so as to avoid the repetition of the confusion that arose in connection with the previous naval expeditions as a result of their engaging in activities without an entirely clear authorization having been given for them in all cases." The Canadian government wanted to know all of the training, research and development projects and scientific work the Americans hoped to accomplish. ${ }^{41}$ This included aircraft activities associated with the task force, which would be scrutinized to ensure that they did not conduct unauthorized overflights over Canadian territory. ${ }^{42}$

Magann also expressed concern about American planners' frustrating lack of knowledge of the directives outlining joint defence publicity. ${ }^{43}$ Past events proved that the Americans did not control publicity as carefully as their Canadian counterparts. Leaks often appeared in U.S. newspapers with stories, often incorrect or exaggerated, of defence activities in the North. Despite repeated requests by the Canadians that the Americans take steps to ensure this stopped, stories continued to appear. ${ }^{44}$ Magann hoped their attitude would change in preparation for the upcoming naval mission and explained to his American counterparts the importance Canada put on limiting the press surrounding Arctic activities.

40 Ibid.

41 Canadian Ambassador, Washington, to Secretary of State for External Affairs (SSEA), 27 March 1948, LAC, RG 25, vol. 3841, file 9061-H-40.

42 L.B. Pearson, Memorandum for Cabinet Defence Committee, Arctic Weather Station Programme, 13 April 1948, LAC, RG 25, vol. 3841, file 9061-G-40. Pearson was quickly informed they would only be used for reconnaissance. A.D. Struble, Deputy Chief of Naval Operations, to Andrew Foster, 19 May 1948, LAC, RG 25, vol. 3841, file 9061-G-40, and Grant, Sovereignty or Security?, 185.

43 Ambassador to SSEA, 27 March 1948.

44 See David J. Bercuson, “'Advertising for Prestige': Publicity in Canada-US Arctic Defence Cooperation, 1946-48," in Canadian Arctic Sovereignty and Security: Historical Perspectives, ed. P. Whitney Lackenbauer (Calgary, 2011), 111-20. 


\section{Observing the Americans}

Canadian officials also set about assuring that they could send more observers on the 1948 mission than in previous years. In 1946 the Canadians were permitted to send three observers to watch over a task force of eight ships, but this was insufficient to observe the activities conducted by the group. In April 1948, the USN's chief of naval operations informed the Canadian Joint Staff that the task force could only accommodate five Canadians. Ottawa found this unacceptable and the Canadian ambassador in Washington, Hume Wrong, sought eighteen spots. He argued to the Americans that the observers' work would benefit everyone and that he could not "overestimate" the Canadian government's interest. Wrong also explained that the Department of Transport planned to bring two to three icebreakers into service over the next few years to assume a greater share of the supply responsibility. This demanded experience, making the department "most anxious to acquire the necessary navigation and construction picture through [Captain Albani Chouinard] who has had much icebreaker experience in waters to the south of those to be visited by the Sea Supply Mission." ${ }^{45}$

To refute a potential American rejoinder that the limited berths on the ships would preclude a large Canadian contingent, Wrong suggested that the Canadian observers would be willing to sleep on the decks of the crowded U.S. ships. ${ }^{46}$ This idea did not sit well with other government officials who never wanted to give the Americans the upper hand while carrying out defence activities in Canadian jurisdiction. "The Americans are very conscious of creature-comforts, and it has been brought home to me in talks...that we have lost face by making this offer," one member of External Affairs noted. "I am so sorry this one slipped past me this year, but it just did not register, somehow (one of the flaws of a militaristic training, no doubt). ${ }^{47}$ The Canadians would never again suggest that their observers could sleep on the floor, below the Americans in their comparatively comfortable cots.

The Geographic Bureau of the Canadian Department of Mines and Resources (DMR) and the USN also debated the observer question. During 1948, the Canadian and American militaries, and even civilian agencies, grew increasingly annoyed with geographer Trevor Lloyd, the opinionated head of the Bureau. A "northern nationalist" who constantly worried about Canada's sovereignty in the North, Lloyd first managed to alienate many officers in the Canadian services when he persisted in requesting

45 H.H. Wrong to Andrew Foster, 17 June 1948, LAC, RG 25, vol. 3841, file 9061-H-40. Captain Chouinard was one of the Department of Transport's senior icebreaker captains. Other notable observers included: a meteorologist from DoT; John P. Kelsall from the Department of Mines and Resources (who represented the NWT Administration and gathered geological and wildlife information); several naval officers including Lt. J.H. MacLean who had been in Washington planning the mission; several RCAF officers; two magneticians from the Dominion Observatory; and Dr. Roman Gadja and Thomas Weir from the Geographical Bureau of the DMR who observed terrain, ice conditions and geography. Ibid.

47 Minute Sheet, Arctic Weather Station Programme, Summer 1948, 23 June 1948, LAC, RG 25, vol. 2127, file Defence: Weather Stations, pt.1. 
information about the Canadian-American defence arrangements not required by the Geographic Bureau. ${ }^{48} \mathrm{He}$ even attracted the ire of External Affairs when he "endangered the machinery for the exchange of reports and other material between the Services of the two countries by going himself or sending assistants to the U.S. Service Departments in Washington to ask for copies of various reports, etc., only part of the contents of which was relevant to his work." The military's dislike of Lloyd became so intense that a rift formed between the Departments of National Defence and Mines and Resources. ${ }^{49}$ While the senior officials at the DMR continued to support Lloyd's actions, the military grew more distrustful of his entire organization.

This atmosphere led to conflict between the military (including the U.S. services) and the bureau. An especially sharp dispute broke out when the DND attempted to stop the bureau from obtaining copies of the USN's report on the Arctic operations of 1947. This distrust for Lloyd and his organization heated up again during the debate over which observers would accompany Task Force 80. The USN singled out all the personnel from the DMR for security checks and "special going over," while observers from the other departments received less intrusive scrutiny. ${ }^{50}$ Eventually External Affairs had to step in and order the Canadian ambassador to tell the Americans that the RCMP had fully examined and cleared Lloyd and his men. "Our feeling in this Department," noted St. Laurent, "is that the explanation of Lloyd's interest in joint defence matters is that his zeal as a geographer has carried him a bit too far in a Department which, of course, has always kept a cautious eye on U.S. activities in the Northwest Territories and especially in the Arctic Archipelago where our claims to sovereignty have not all been formally acknowledged by the United States." ${ }^{51}$ Lloyd's interest and habit of investigating American activities led to some tense moments in the lead up to the resupply mission.

Although several would indeed bunk on the deck, all eighteen Canadian observers from several different government departments were allowed to accompany Task Force 80. In their hands were operation plans for the expedition, including details of all the experiments that the Americans hoped to carry out. Nevertheless, the government did a poor job explaining to the observers exactly what was required of them and offered no additional training. While many were given specific instructions from their own departments on the scientific research they should conduct, few knew how they should properly supervise the Americans. Of all the observers, Chouinard, who led the Canadians on Edisto, received the most instruction for what he should be looking for at a technical level. He was told to keep track of ice conditions, ice reconnaissance and how the ships handled in the ice and compare their experiences with operations in the St. Lawrence. Based on these observations he was to report on the type of ship Canada

48 SSEA to Canadian Ambassador, Washington, 28 June 1948, LAC, RG 25, vol. 3842, file 9061-J-40, pt.1. On earlier objections of the Joint Intelligence Bureau to the involvement of the new civilian bureau collecting "strategical information," see Grant, Sovereignty or Security, 220-21.

49 SSEA to Canadian Ambassador, Washington, 28 June 1948.

50 USSEA to G.L Magann, 15 September 1948, LAC, RG 25, vol. 3842, file 9061-J-40, pt.1.

51 SSEA to Canadian Ambassador, Washington, 28 June 1948. 
required for Arctic operations: a commodious ice-capable vessel, which could be used to carry substantial cargo; or a very powerful ship with fine lines built for breaking heavy ice, but large enough to escort other cargo vessels. He was also to report on the value of helicopters to ships' operations and the need for fuel storage at strategic points. Shortly before the resupply mission, several Swedish officers had visited Canada to investigate icebreaker services and they claimed to have successfully used radar to observe various ice formations and thickness. Chouinard was to report on whether or not this was accurate. ${ }^{52}$ As leader of the observers, however, the expectations of him were unclear.

The observers from the Geographical Bureau and the Department of Mines and Resources also received more specific instructions from Trevor Lloyd. C.C. Eberts, the secretary of the Canadian Section of the PJBD, reported to Magann that:

while it would not surprise me if Trevor Lloyd laid it on a bit thicker than necessary in preparing the instructions to the Geographical Bureau's two representatives, it had, after all, been made clear in your request to the United States authorities for accommodation that those representatives would have quite broad function and I suppose that instruction to any geographers sailing off into the little-known north, where the few place names are those of somewhat ancient expeditions, or their leaders, could sound a little grandiose. Also, Mines and Resources are, of course, rather conscious of the fact they "administer" the Arctic - in a legal sense at least. ${ }^{53}$

Throughout the summer of 1948, Lloyd followed the annual Arctic sea supply mission like a hound dog, trying to sniff out American indiscretions. His men on board, like Tom Weir, kept him well informed of the progress of the task force and reported any questionable or worrisome activities. Unfortunately, despite all of the precautions taken during the planning stage of the resupply mission, there was plenty to report.

\section{The Voyage of Task Force 80}

On 15 July 1948 the small task force pulled out of Boston harbour and headed for Arctic waters. Edisto set a course for Godthaab (now Nuuk), Greenland where it delivered supplies and survey equipment to the Danish authorities. In the meantime, Eastwind made it to Dundas Habour, Devon Island, in the Canadian archipelago on 23 July and picked up an automatic weather station for transfer to Resolute. Soon after, the icebreaker set course for Greenland and rendezvoused with Edisto and Wyandot off Thule, Greenland. As Wyandot travelled alone to the central hub of the weather station system at Resolute Bay, the two icebreakers made their tumultuous journey to Ellesmere Island, captured the furthest North record, and arrived off Dumbbell Bay on 2 August. Here Edisto started to offload supplies for a new weather station, at what is now known as Alert. As it started to shuttle the cargo to shore, however, the polar pack ice began to drift south and fill in the bay, pushing the ships to shore. Both icebreakers quickly made

52 J.C. Lessard, Deputy Minister, Department of Transport to Captain Albani Chouinard, Master Saurel, 7 July 1948, LAC, RG 25, vol. 3842, file 9061-J-40.

53 C.C. Eberts to G.L Magann, 15 September 1948, LAC, RG 25, vol. 2127, file Weather Stations Supply Mission, 1949. 
for open water, but the action of the ice was so quick that two landing craft, with an observer and fifteen men, were stranded on the beach. ${ }^{54}$

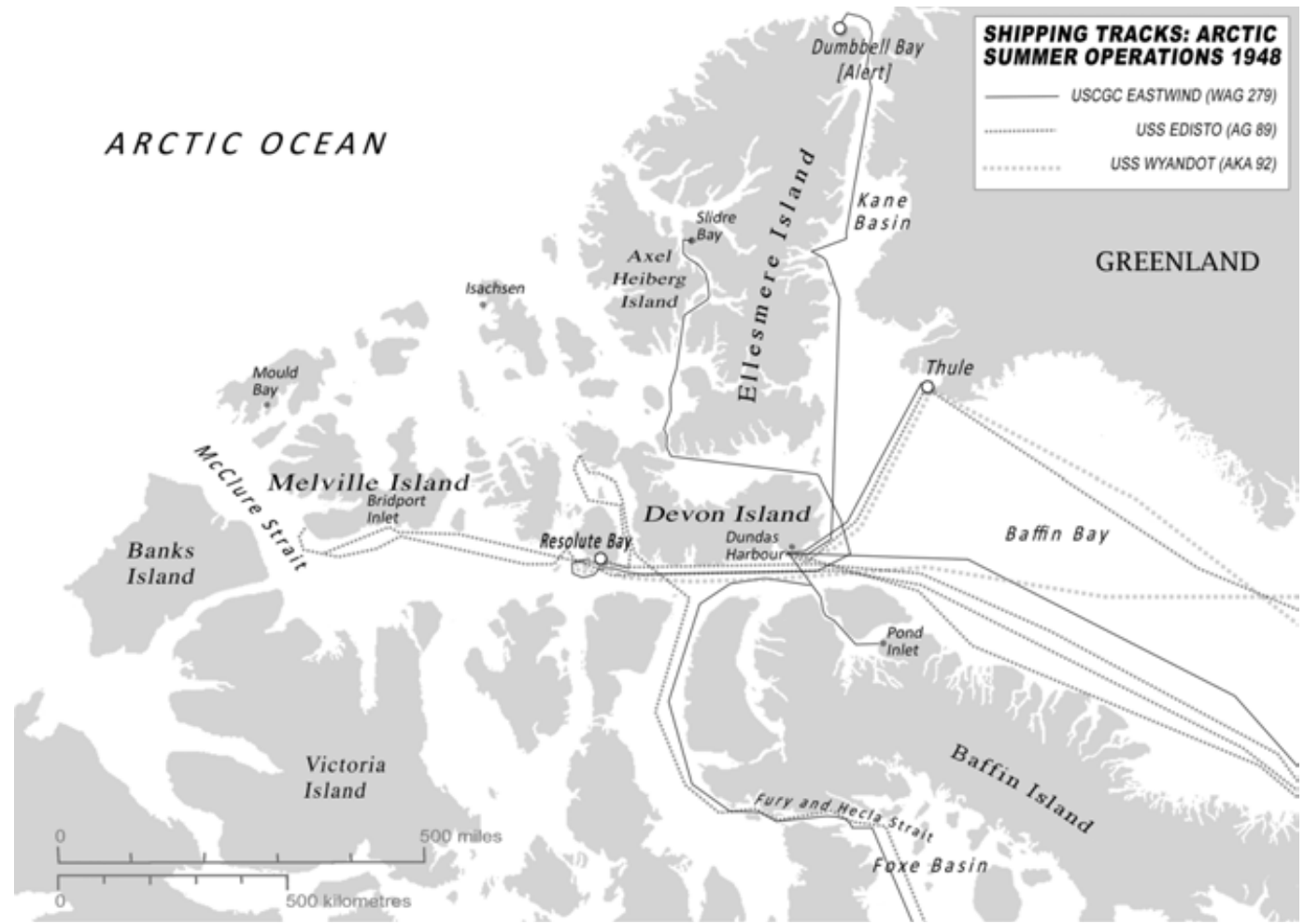

Illustration 3: Shipping Tracks from Task Force 80. Map drawn by Jennifer Arthur based on "Ships \& Aircraft Tracks Arctic Summer Operation of 1948," Library and Archives Canada, RG 25, Vol. 3841, File 9061-G-40.

The ships retreated to Black Point and waited for the ice conditions to change. On 6 August a strong westerly breeze finally opened up a passage between the pack ice and shore, and Eastwind ran in to land the remainder of the construction supplies for the planned station and rescue the marooned men. ${ }^{55}$ With their mission on the northern end of Ellesmere Island complete, the ships slowly pushed through the ice to Fort Conger, where Edisto, still limping along without its port screw, was almost driven ashore by the ice on 7 August.

On 10 August, Edisto reached Dundas Harbour and immediately made for Boston

54 Dufek to United States Atlantic Fleet, 7 August 1948, Dufek Papers, Task Force 80 Box 1, Correspondence 1948.

55 Chronological Summary of Main Events of Task Force 80, July 26 to August 8, Compiled from Interim Reports by Dr. R.T. Gajda and Mr. T.R. Weir, Observers for the Geographical Bureau, LAC, RG 85, vol. 302, file 1009-5-1. The supplies landed included a large T-9 tractor, cargo sleds, drums of fuel, a Jamesway Hut, Nelson Heater, stoves, general camp stores and lamps. 
for repairs of its damaged propeller and shaft. The next day, Eastwind dropped a large amount of fuel off at Pond Inlet before heading to Resolute Bay, where it rejoined Wyandot. On 13 August, the two ships started the long process of offloading supplies, although the whole operation was difficult because of ice lodged in the bay. After several days watching the operation unfold, Eastwind parted company with Wyandot and headed for the station at Slidre Bay, only to be called back on 17 August by an urgent message from the transport ship saying it was caught in the ice and being driven to shore. The icebreaker returned to Resolute as fast as possible and found that the cargo ship had managed to make clear water. It had not, however, escaped undamaged. The ice had bent the cargo ship's propeller blades, causing vibrations throughout the ship and a significant loss of speed.

Undeterred by this near disaster, another attempt was made to unload the supplies for Resolute on 20 August. Heavy ice again rolled into the bay, stymied all progress, stranded forty men on the beach, and almost crushed a landing craft. Once more Wyandot was threatened by ice and the icebreaker had to tow the ship clear. Still unable to finish unloading supplies at Resolute, Eastwind left once more for the station at Slidre Bay on 25 August and reached the site three days later. It landed supplies there without incident - the first part of

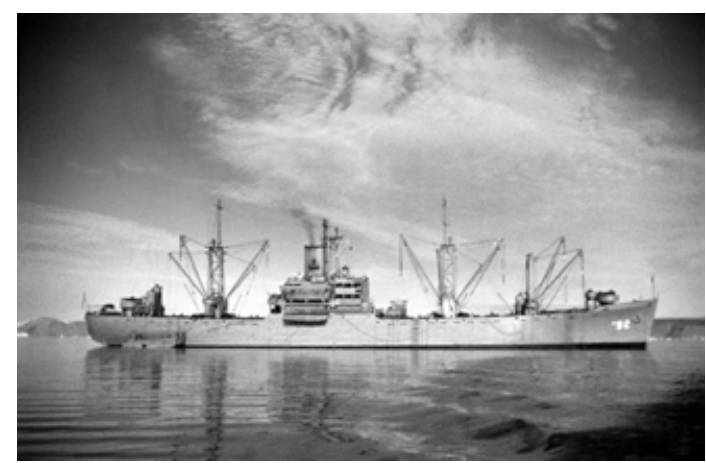

Illustration 4: The Andromeda-class cargo ship USS Wyandot "in all its glory," 1948. Photo: Alan J. Faller. the resupply operation to go as planned. The next afternoon the icebreaker headed back to Resolute, rendezvousing with the newly returned Edisto on 2 September. Though the unloading of supplies was continuously upset by drifting ice in the bay, by 4 September all materials had been transported to shore. Task Force 80 then dispersed, with Wyandot heading back to Boston via Godhavn (Qeqertarsuaq), Greenland. Eastwind escorted the transport to Baffin Bay before it returned to Prince Regent Inlet to explore the western end of the Hecla and Fury Strait. On 6 September the ship proceeded through the channel, facing dangerous shoals at only twelve fathoms. It used a landing craft with echo sounding to find a channel through the strait, noted errors in the survey maps, took soundings, charted the coastline, kept an ice record, and managed to make it to Foxe Basin at the eastern approach to the strait. ${ }^{56}$ Eastwind had set a new record as the first vessel to navigate the strait and thus open "up a new route to the northern Canadian Arctic." ${ }^{57}$ The ship proceeded through Foxe Basin and the Hudson Strait to return to Boston on 19 September.

56 Department of National Defence, Commander Thomas Fife, Observer's Narrative of USN Task Force 80 (hereafter "Fife Narrative"), 15 July to 19 September, 1948, 24 September 1948, LAC, RG 25, vol. 3841, file 9061-G-40. 
At the same time, Edisto attempted to perform a reconnaissance of the approaches to Prince Patrick Island. The icebreaker made a survey of the area around Bridport Inlet on 6 September, which representatives of the U.S. Weather Bureau and the RCAF selected as a possible site for a satellite weather station. Soon after the hard ice of McClure Strait forced the ship to abandon its attempt to survey the approaches to Prince Patrick. Before it left the area, however, the ship also tried to investigate the sea approaches to Isachsen via the Wellington Channel and Penny Strait. Again it faced impenetrable ice and after a few days Edisto turned around and took the new route found by Eastwind back to Boston, arriving on 25 September. ${ }^{58}$ Thus ended the cruise of Task Force 80. The controversy, however, was far from over.

\section{Canadian Sensitivities and American Indiscretions}

On 8 August, Tom Weir sent his report on Edisto's accomplishment to Trevor Lloyd and predicted the event would spur the Canadian government to invest more in the Arctic. ${ }^{59}$ Specifically, Weir hoped the American accomplishment would embarrass his government into deploying its own ships into the region. He was correct about the embarrassment. A report on the sea supply mission explained that "this event is, you will see, partly 'buried' in the draft release simply because it appears dangerous, from the sovereignty point of view, to make an official announcement to the effect that the ships went further afield than did that of the British explorer Nares (who went much further himself by sled). ${ }^{60}$ David M. Johnson, the head of the American and Far East Division at External Affairs, suggested that the press statement on the expedition not mention the journey of the Edisto. He argued that those in the United States who still toyed with the idea of claiming territory in the Canadian North often focused on the northern part of Ellesmere Island and any admission of the Edisto's accomplishment might encourage them. ${ }^{61}$ An ideal solution would avoid any sovereignty fallout and avert embarrassment. Canadian officials were realistic, however. At least one of the 700 U.S. navy personnel assigned to the mission would leak the accomplishment, ${ }^{62}$ so Ottawa chose to release the news to the press - but made the extraordinary feat as ordinary as possible.

Another event during the mission irritated the Canadian government more than Edisto's voyage past Cape Sheridan. Prior to granting approval for the expedition, Canadian officials insisted that the USN provide the proposed route of the task force and that U.S. commanders seek Canadian approval before they took any alternate routes. ${ }^{63}$

58 Ibid.

59 Tom Weir to Trevor Lloyd, 8 August 1948, LAC, RG 85, vol. 302, file 1009-5-1.

60 Memorandum for SSEA, 23 September 1948, DCER, vol.14, 1948, 1538; and Draft Press Release, 27 September 1948, DCER, vol.14, 1948, 1540. Admiral George Nares was a British naval officer who avidly explored the Arctic in the 1870 s, including a voyage in search of the North Pole on board the Alert.

61 D.M Johnson to Magann, 24 September 1948, LAC, RG 25, vol. 3841, file 9061-G-40.

62 Memorandum for SSEA, 23 September 1948.

63 Counsellor, Embassy United States to Assistant Chief, Commonwealth Affairs Division, Department of State, 27 September 1948, DCER, vol. 14, 1948, 1539-1540. 
Unfortunately, the Americans decided to alter their course and transit the Fury and Hecla Strait on the return trip to Boston. Task force commander Captain Dufek notified the senior Canadian observer, but he failed to inform the Canadian government. ${ }^{64}$ Since the Wyandot returned via the proposed original route, Canadian officials later concluded that "it is plain from the information already available that the change was made not for operational reasons but because Captain Dufek wished to do so and because he had forgotten the instruction which said he was not to change his route without permission." 65 Dufek's actions also annoyed the Canadians because the two U.S icebreakers became the first ships to successfully transit Fury and Hecla Strait.

This breach of protocol challenged Canada's control over what happened in the Arctic. Canadian officials wanted to ensure that Americans on future naval operations undertook "no further excursions into areas that are quite irrelevant to the weather station programme." ${ }^{\prime 66}$ The Canadians also informed the USN that deviation from previously agreed upon plans would greatly impede the ability of the U.S. to secure approval from Canada for subsequent defence projects. ${ }^{67}$

Although several Canadian officials wanted to launch a formal complaint, George Magann, a counsellor at the Canadian embassy in Washington, doubted the validity of Canada's case. Before jumping to hasty conclusions, he investigated more deeply and discovered that RCN Commander Thomas Fife, an observer on Edisto, had telephoned Ottawa to ask Naval Headquarters for charts of the Strait. The chief of the naval staff asked the Canadian Joint Staff in Washington to find out why the task force required them. While the USN did not plan to enter the strait, they discovered, the Americans intimated that plans could change and the charts would be essential. In this case, the U.S. chief of naval operations - an American, not a Canadian - would be consulted, and there was no evidence that Canadians had expressed any concern. ${ }^{68}$

Magann's investigation revealed troubling issues. All of the conversations had taken place over the telephone, leaving him with no documentary evidence. In addition, Lieutenant Russell, the joint staff officer who had looked into the American request for the charts for the Chief of the Naval Staff, had just taken his leave in Mexico. As a consequence, Magann had learned of developments second-hand from another officer, who recalled that Russell never told the Americans that they would have to seek Canadian permission before changing course. "If, of course, it turns out that there is some usable evidence that Russell told the United States Navy that the approval of the Canadian Government must be obtained," Magann noted, "our hand in taking this up with the State Department would be greatly strengthened."

64 Memorandum by C. C. Eberts, 19 November 1948, LAC, RG 25, vol. 5912, file 50197-40.

65 Magann to Johnson, 13 October 1948, LAC RG 25, vol. 3841, file 9061-G-40; Heidt, 155.

66 Memorandum by Defence Liaison Division for Acting Head, Defence Liaison Division, 19 November 1948, DCER, vol.14, 1948, 1544-1555.

67 Counsellor, Embassy United States to Assistant Chief, Commonwealth Affairs Division, 27 September 1948.

68 G.L. Magann to D.M. Johnson, 27 September 1948, LAC, RG 25, vol. 3841, file 9061-H-40. 69 Ibid. 
any. Indeed, Russell may have approved the changing of the route through his silence, making the whole issue at least partially Canada's fault.

A lack of effective coordination in continental defence planning played a role in the USN's decision to use Fury and Hecla Strait. While the American commander understood that he had to consult a Canadian authority if he changed the mission's route (and he failed to do this), the lack of concerted effort on the Canadian side heightened the confusion. Accordingly, Magann wrote a gentler and less accusatory letter to William Snow, his contact at the State Department, than he had originally intended. He inquired about what happened and reminded the State Department of the need to inform the Canadian government before deviating from approved plans. ${ }^{70}$

The Americans did not accept the gentle criticism of their actions. Snow replied that prior to the voyage the Canadian government had only requested the probable routes, which left the USN with the impression that the routes need not be rigidly followed. After all, the commander required some operational latitude given the hazards of travel in Arctic waters. In addition, one of the Canadian observers on the mission sponsored the decision to use Fury and Hecla Strait. ${ }^{71}$ Magann saw "a great deal of merit in Mr. Snow's implied criticism of the relatively loose way we tie up affairs of this nature,"72 and argued that a formal exchange of letters should lay out the conditions that the Canadian government wanted followed prior to the next Arctic mission. Magann, however, remained convinced that it would have been "common sense on the part of Captain Dufek to send telegraphic notice that he had found it necessary to change the route for operational reasons." ${ }^{, 73}$ Satisfied that the USN would take disciplinary action against Dufek, the Canadians made no formal complaint - and were reassured when they learned that the commander was "in very hot water" for his mistake. ${ }^{74}$

The American tendency to act without permission upset the Canadian observers on the mission and officials in Ottawa more than anything else. Throughout the mission, senior U.S. Army and Navy officers visited the ships and the stations they were supplying, often unannounced. At several points, thirty or forty high ranking officers descended on the little station at Resolute to witness the resupply operations first hand, much to the chagrin of the Canadian officer-in-charge there, who had to feed them and find them sleeping quarters. ${ }^{75}$ Ottawa picked its battles and did not complain to Washington about the issue, but it did register its disapproval when Americans forgot to adhere to Canadian regulations. During the mission to northern Ellesmere Island, Charles Hubbard, the head of the American Arctic meteorological program, found a cairn erected by American explorer Robert Peary in 1906 and took a whisky bottle full of historical

70 Ibid.

71 William P. Snow to Magann, 11 October 1948, LAC, RG 25, vol. 3841, file 9061-G-40.

72 Magaan to Johnson, 13 October 1948, ibid.

73 Ibid.

74 Memorandum of a Conversation with Lieutenant J.H MacLean, 1 October 1948, LAC, RG 85, vol. 2083, file 7140-3.

75 Wright to R.A. Gibson, 22 November 1948, ibid. 
documents from it onto the Eastwind. Captain Dufek asked the senior Canadian observer, Commander Fife, to open the bottle and review the papers. The task force commander mentioned that he wanted to take the relics to the naval academy at Annapolis. Fife asked the Americans if he could make copies of the documents - which seemed to approve the American action, much to the chagrin of the other observers (especially those from the Geographic Bureau). "About this time all members of the Canadian Observer Group called on me and requested that I, as the senior Canadian present, demand custody of these documents," Fife recounted. "The opinions voiced had all the makings of a very unpleasant situation which was averted when I advised them that due thought had been given to such action and I had decided that it would be neither polite or politic to make any such demands at the moment." ${ }^{76}$ Fife relayed the information to his superiors, but he feared that a more formal complaint at that time might have led the Americans to exclude the Canadians from subsequent discoveries made by the task force. Instead, he told observer Tom Weir to present the Americans with a copy of the Ordinance Respecting the Protection and Care of Archaeological Sites. An agitated Hubbard denied that the cairn constituted an archaeological site, but the Canadians insisted that it did. ${ }^{77}$ More formal action, however, was left to senior officials in the nations' capitals.

Trevor Lloyd, kept well informed by his observers on the ships, pressed the issue in Ottawa. He found few people in the capital who shared his level of concern about American activities in the Arctic. "I am

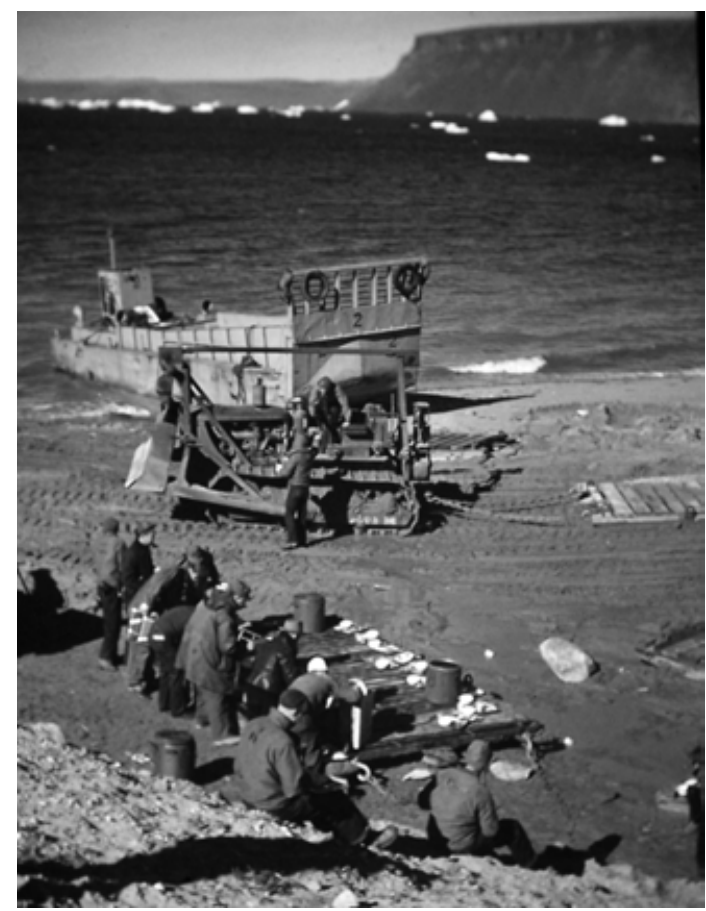

Illustration 5: Lunchtime at Thule, 1948. Photo: Alan J. Faller. disappointed that no one else in town seems to know much about what is going on in the Task Force, or if they do, that they are keeping it to themselves," he complained in August. "I have checked with Jim Wright who has no information, with the Navy and the Department of Transport, but none of them have been much help." ${ }^{78}$ Thus, when Lloyd finally secured evidence of an American "indiscretion" in the Canadian Arctic, he tried to

76 Fife Narrative, 15 July to 19 September, 1948, 24 September 1948. The documents came from Captain Peary's USN expedition of 1905 and from the voyage of British explorer G.S. Nares in 1876.

77 Fife Narrative. Several American officers intimated that the Canadians acted secretively and abrasively during the affair, and relations onboard chilled for a short time. 


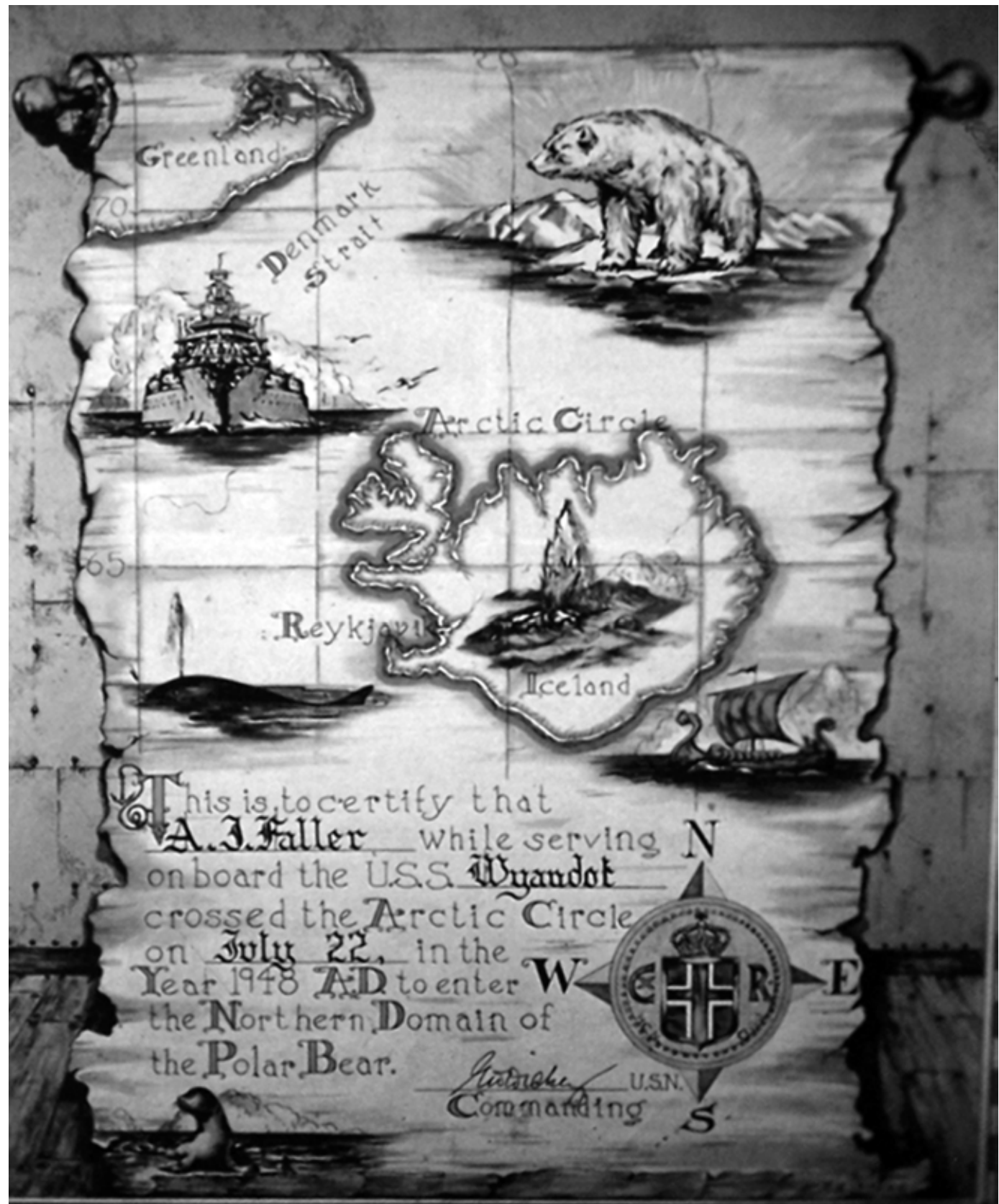

Illustration 6: Alan J. Faller's certificate for crossing the Arctic Circle on the USS Wyandot, 22 July 1948. Photo: Alan J. Faller.

make a real issue out of it. Hugh Keenleyside tried to calm the head of the Geographic Bureau in a letter dated 30 August, explaining that Captain Dufek simply followed the usual custom of commanders of exploratory expeditions by removing the original documents and replacing them with exact copies. Furthermore, Dufek had included the 
Canadian observers in the task. ${ }^{79}$ Both the Americans and Canadians had erred. The Canadian observers should have known about the archaeological regulation, chastised Hubbard for removing the whiskey bottle without a permit, and confiscated the materials. They had much to learn.

While at Slidre Fiord several Americans broke another Northwest Territories ordinance, though this time the Canadians responded more appropriately. During the resupply operation, two American servicemen went ashore and shot four hares in violation of the Canadian Game Laws for the Arctic Preserve. John P. Kelsall, an observer from the Dominion Wildlife Service, informed an American officer that he had no choice but to tell Ottawa about the situation - even though he understood that there was not an attempt to undermine Canadian authority. "It was quite obvious from their actions, but extremely peculiar, that both men were in complete ignorance of the no hunting regulations," Kelsall explained in his report. Nevertheless, the Americans took the offense seriously and publicly punished both men. Other than this case, Kelsall emphasized, "all game laws have been adhered to in the most gratifying manner and ... there can be no doubt in the mind of anyone that Canadian Game laws will be respected at all times." 80

Perhaps the most noticeable and damning American indiscretion occurred after the ships returned to Boston. Prior to Task Force 80's departure, Canada insisted that joint press releases only be issued at the beginning and end of the mission and that the publicity directives for joint defence projects be followed to the letter. As soon as the expedition returned to Boston, however, leaked information began to find its way into the newspapers, including a front page story in the New York Times. Worse, U.S. government sources intimated that the Truman administration wanted to release more details on the expedition but Ottawa would not allow it. ${ }^{81}$ The Canadian government looked like it was hiding something from the public, and the accusation raised suspicion about the defence

79 Hugh Keenleyside to Trevor Lloyd, 30 August 1948, ibid.

80 John P. Kelsall to Lewis, 31 August 1948, ibid. See also Smith, "Weather Stations." In other situations the observers made careless errors. In an incredible lapse of judgement, Captain Chouinard informed his American hosts of his desire to name points in the Arctic - rarely visited by Canadians - after Captain Dufek and the other American officers on the expedition. While Ottawa officials managed to avoid an awkward situation by claiming Canada did not name places after living people, a wiser Canadian observer would never have created such a situation. Memorandum by Defence Liaison Division, 19 November 1948, LAC, RG 25, vol. 3346, file 9061-40, pt.1. Chouinard did not even realize his error when the Canadian government rejected his request and he was upset by the stipulation that land could only be named after a deceased person. Report of Captain A.C Chouinard, DOT Remarks and Recommendations of Observer: Recommendation for a Future Trip to the Arctic, LAC, RG 85, vol. 828, file 87-2-1, pt.2 (hereafter "Chouinard Report").

81 Memorandum by Defence Liaison Division for Acting Head, Defence Liaison Division, DCER, vol. 14, 1948, 1543-1544. The New York Times published a front-page story describing Hubbard's discovery of the Peary cairn in minute detail and also described the task force's voyage through "straits and channels believed never to have been navigated before.” Murray Schumach, "U.S. Vessels Find 1906 Peary Cache," New York Times, 28 September 1948, 1. 
activities occurring in the Arctic. The leaked reports and the secrecy about the mission made the press far more interested than it otherwise would have been.

To their credit, most senior Americans understood the seriousness of the situation. In his report, Dufek commented that "while CANADIAN reaction varied among the various branches of government from taking a serious viewpoint of the inadvertent breach of the agreement concerning publicity to regarding the whole affair as a tempest in a teapot, never-theless it is vital to harmonious Canadian-United States relations in joint ventures that every effort be made to confine publicity to the agreed upon." ${ }^{82} \mathrm{He}$ suggested that both governments strive to release an official story far more quickly for the next Arctic resupply mission.

Charles Hubbard, enjoying his position in the limelight a little too much, was the main source of the press leaks. William Snow sat him down and told him that the rules on publicity prohibited him from making any statement without approval from both governments. Quotes from Hubbard still appeared in the news, and a photo of him in his office, looking every bit the part of the Arctic explorer with a roll of maps on his lap, appeared in The Times. Snow was as angered by Hubbard's "mania for publicity" ${ }^{83}$ and this blatant breach of protocol as the Canadians. ${ }^{84}$ The leaked stories were not part of an American conspiracy to undermine the Canadian position in the Arctic, but they did remain a source of bilateral tension.

Following the difficulties with publicity on the task force, the Canadians took every step to ensure the mission faded in the public's memory. The under-secretary for external affairs explained that the authorities in Ottawa "wanted the Mission to drop into obscurity," ${ }^{35}$ including Minister of National Defence Brooke Claxton who instructed that "everyone... forget about the Sea Supply Mission.." ${ }^{86}$ Deflecting attention away from Arctic defence projects would have the dual benefit of reducing public anxiety about the extent of U.S. activities in the region and of avoiding any further strain in Canada's relations with the USSR ${ }^{87}$ Little scared the Canadian government more in those years than stories about defence projects spreading throughout its Arctic, given its limited capabilities to act independently. ${ }^{88}$

82 Report of Arctic Summer Operation, 1948, U.S. Navy Task Force Eighty.

83 Canadian Ambassador to SSEA, 29 September 1948, LAC, RG 25, vol. 3841, file 9061-H-40.

84 In late October, Hubbard requested permission to appear on the radio program We the People to discuss the 1948 supply mission, but was rejected by External Affairs. G.L. Magann to W.P. Snow, 21 October 1948, LAC, RG 25, vol. 2127, file Weather Stations Supply Mission, 1949; Heidt, 156.

85 Johnson to Lessard, 1 November 1948, LAC RG 25, vol. 3841, file 9061-H-40.

86 Minute Sheet, Sea Supply Mission of 1948, LAC, RG 25, vol. 2127, file Weather Stations Supply Mission, 1949.

87 Magann to Snow, 21 October 1948; The Americans were also quick to deflect public attention away from military operations in the North out of concern over how the Soviets would view such activities. D.W. Middlemiss and J.J. Sokolsky, Canadian Defence: Decisions Determinants, (Toronto, 1989), 17; Elliot-Meisel, "Royal Canadian Navy in Arctic Waters," 27.

88 See, for example, Adam Lajeunesse, "The Distant Early Warning Line and the Battle for Public Perception,” Canadian Military Journal VIII, no.2 (Summer 2007), 51-59. 


\section{The Observers Report In}

Accompanying these problems was a wave of complaints from the Canadian observers lamenting their treatment on the mission and the general situation in the Arctic. Lieutenant J.H. MacLean, a Canadian observer on loan from the RCN, explained that "with the exception of a few of the highest officers on the mission, none of the United States personnel aboard was aware that the mission was a joint enterprise." Most of the Americans did not realize the Canadians contributed to the resupply mission and commanded the weather stations. According to MacLean, everyone seemed to think that Hubbard, who "palpably kept himself in the limelight," controlled everything. The lieutenant argued that Canada needed to provide physical evidence of its participation in the Arctic projects. Ideally, either RCN ships should accompany the next mission or RCAF aircraft make an appearance overhead. Without some kind of symbol representing Canada "the United States personnel were left with the firm impression (not altogether unfounded) that they were the only people taking an interest in that part of the Arctic." 89

The other observers on the mission echoed MacLean's criticisms and suggestions, especially on the need for symbolic displays of sovereignty. Kelsall complained about the USN's tendency to treat the Canadian civilian scientists as an "unavoidable nuisance" and thought the Canadian flag had to be flown more in the region. ${ }^{90}$ Captain Chouinard lamented that Canada did not have a ship capable of operating in the Arctic waters, providing a more permanent Canadian presence. "While waiting to have a proper ship to be built for this region, it is felt that steps must be taken now to show the Canadian flag in one of the most important parts of the world due to its nearness to the Pole," he advised. "This importance is stressed by other foreign countries who have operated in the area for the last three seasons." Chouinard also wanted Canada to do more to investigate the potential geological and meteorological value of Ellesmere Island. ${ }^{91}$ Commander Fife explained that Canada would need to strengthen its sovereignty in the Arctic before the U.S. started to "consider it hers by reason of investment made." He wanted Canadian capabilities in the region built up, for "it is better to be self-reliant than wait for the crumbs which fall from the rich man's table." ${ }^{92}$ He suggested they try and find young Canadians willing to dedicate parts of their lives to full time service in the Arctic.

Fife was one of the most active observers in lobbying for more effective Canadian control and supervision in the region. He was worried about the Americans, much like Trevor Lloyd with whom he corresponded regularly. Lloyd, who had grown discouraged because of his alienation from officials who held important information on Arctic defence projects, planned to resign. Upon learning this news, Fife wrote him a strong letter of support. "Up North we caught a story that you were getting fed up with

89 Memorandum of a Conversation with Lieutenant J.H MacLean, 1 October 1948, LAC, RG 85 , vol. 2083, file 7140-3. MacLean suggested the RCAF fly over and around the task force to provide evidence of a Canadian presence.

91 Chouinard Report.

92 Fife Narrative, 15 July to 19 September 1948. 
your job and were going to quit," Fife lamented. "I, and many others[,] particularly those we meet in the North[,] sincerely hope it isn't so, [as] we all feel that this great and growing country of ours needs you." The sea supply mission gave Fife "a strong conviction that if we don't get busy and vein the N.W.T. as an all Canadian show we shall have some one doing it for us, and not 'By the powers vested therein' but by right of 'Dollars invested therein." 93 To avoid this tragedy, men like Lloyd would need to keep pressuring the government to pay attention — and devote resources to - a Canadian Arctic presence.

In their extensive report on Task Force 80, the RCAF observers, Squadron Leader G.M. Ewan, Flight Lieutenant A.L. Jewett, and Flying Officer V.W. Eldridge echoed Fife's call for more government spending in the North. Offering a litany of suggestions for how to establish better Canadian control in the region, they called for more aids to navigation, improved charting and surveying, an accelerated air photography program, and icebreakers capable of operating in Canada's Arctic waters. If the Canadian government wanted to better control the region, it had to know what was up there. "It is cold comfort to the navigator, as his aircraft crashes, that he has discovered a new island or mountain range," they explained. Transport was "the key to the Arctic. It was distasteful to see another nation, over whose foreign policy we have no control, taking the initiative, obtaining the experience, and in fact holding this key to such a large part of Canadian territory... Whatever the cost, the Canadian government must control this key to our Arctic Islands." 94 While other observers focused on more symbolic displays of Canadian sovereignty, these men stressed the need for functional capabilities.

Observers also sought better training for subsequent missions and asked that an official Canadian leader be assigned to the observer party. ${ }^{95}$ Squadron Leader J.G. (Gary) Wright complained that the government chose its observers at the "eleventh hour last summer and there was no attempt to brief even the leaders of the two Canadian parties in their responsibilities." 96 He complained that neither Fife nor Chouinard "had more than a very hazy knowledge of Canadian Arctic problems." In fact, Wright and Kelsall, with their experience in the DMR and the Northwest Territories Administration, were the best briefed men on the ship in regards to Arctic issues. As junior observers, however, their opinion was rarely sought. Furthermore, the composition of the group was a mistake. There were far too many overlapping interests, ill-defined limits, and little coordination between the military and civilian observers. ${ }^{97}$ All told, the lack of observer training and

T. Fife to Trevor Lloyd, 17 September 1948, LAC, RG 85, vol. 302, file 1009-5-1.

RCAF Observers' Report, United States Naval Task Force 80, LAC, RG 25, vol. 4254, file 9061-G-1-40.

J.G. Wright to Gibson, 22 November 1948; Memorandum of a Conversation with Lieutenant J.H. MacLean, 1 October 1948, LAC, RG 85, vol. 2083, file 7140-3.

Wright to Gibson, 22 November 1948.

G.M. Ewan, A.L. Jewett, V.W. Eldridge, RCAF Observers' Report on United States Naval Task Force 80, LAC, RG 25, vol.4254, file 9061-G-1-40. Although the Canadians considered the sea supply missions to be a civilian undertaking with USN simply lending a "helping hand," the naval personnel on the voyage refused to talk as freely to civilians as they did 
their lack of communication with one another showed throughout the mission.

\section{Lessons Learned}

On the operational level, the cruise of Task Force 80 had been a success. It accomplished a great deal beyond simply resupplying the weather stations. Hydrographic, geodetic, oceanographic and associated intelligence gathered during the mission corrected Arctic navigational charts. Potential airfield, weather station, and Long Range Aid to Navigation (LORAN) sites were identified for future development. The task force learned much about the ice in the region, its movements, and its dangers. A litany of other tests had been successfully conducted on cold weather clothing, automatic weather stations, ordinance, the magnetic field, and communications.

The Task Force also learned from what went wrong. The damage sustained during the mission emphasized the need to protect ships' propellers and their shafts from the ice. Furthermore, the problems experienced by the task force seemed to indicate that the current concept of ship operations was wrong. Edisto and Eastwind led a thinskinned cargo vessel, with a relatively weak hull structure and propellers near the water surface, into ice-choked areas. Vessels built specifically to bring cargo to the Arctic regions - part icebreaker and part cargo ship - were needed. Above all else, the experiences punctuated the need for more work and investigation. In his final report, Dufek noted that:

The strategic importance of the regions of the Arctic and the necessity of our military forces being able to operate there efficiently is well understood. The Task Force Commander can only add his strong recommendation that naval forces continue to operate yearly in the Arctic in order to provide training and experience and gather additional, much-needed information on a vast area which is even yet but little known. The Task Force Commander desires to stress the need for research and development of equipment for operations in the Polar regions.

Part of that research and development had to involve an update of Canadian charts and topographic maps, which were very poor. ${ }^{98}$

The operation also provided the Canadians with information about the type of

members of the armed forces. Consequently, MacLean suggested that in the future the leader of the Canadian party and most of the observers should come from the armed forces. Memorandum of a Conversation with Lieutenant J.H. MacLean, 1 October 1948. Other observers commented that their hosts gave them little access to data collected during the voyage. Memorandum by Defence Liaison Division, 19 November 1948, 1543-44. Not all the observers shared these sentiments, however, indicating that limitations on access reflected personality more than American policy. Tom Weir, Trevor Lloyd's "eyes and ears" in the Arctic, reported that the Americans officers were very congenial and made everything available to the Canadians upon request. He found them more friendly than a lot of the Canadian observers on the mission. Weir to Trevor Lloyd, 8 August 1948, LAC, RG 85, vol. 302, file 10090-5-1. Nonetheless, ensuring proper treatment of Canadian observers remained a priority in planning and executing subsequent missions and defence projects in the Arctic. 


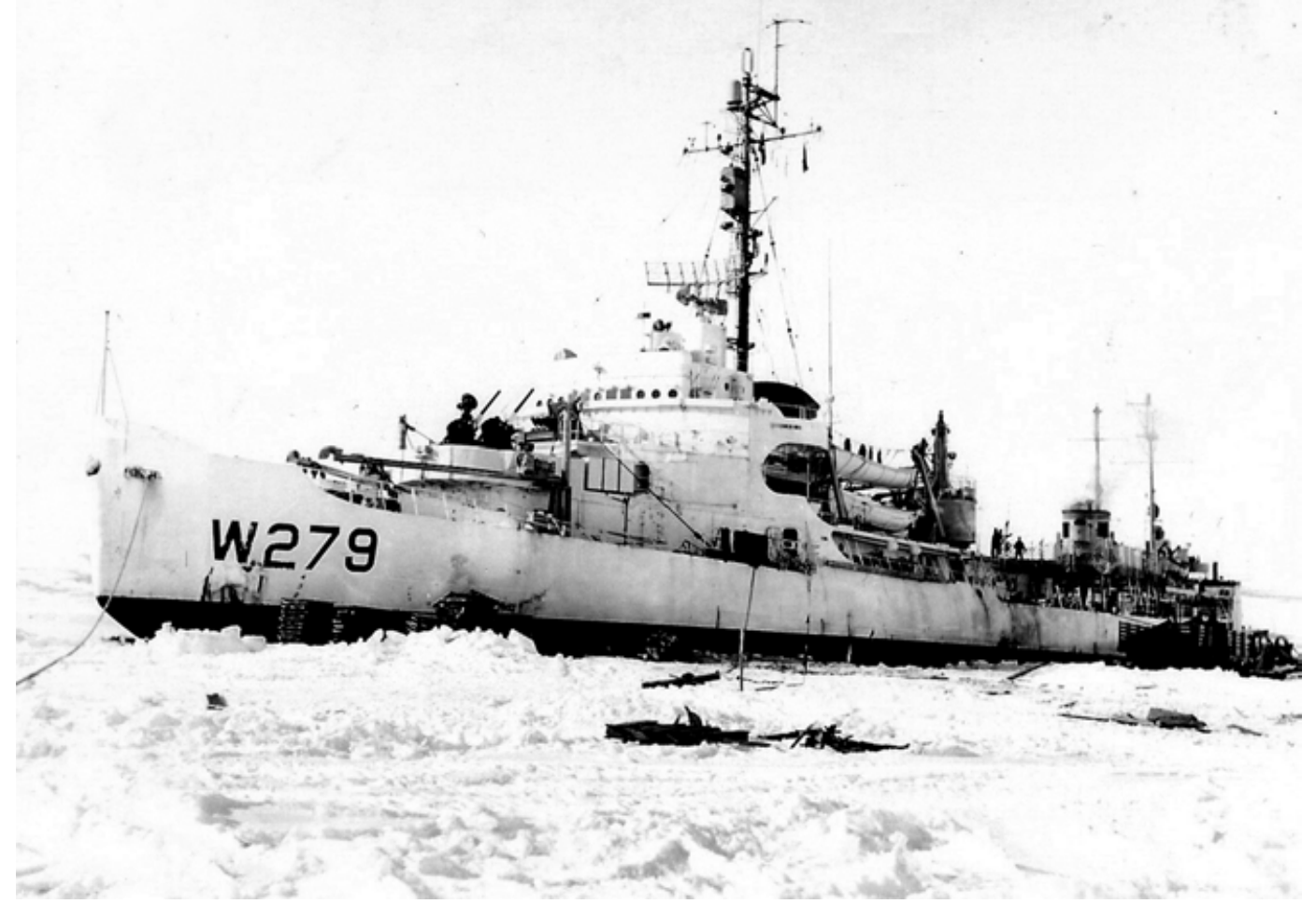

Illustration 7: The Wind-class icebreaker USCGS Eastwind (WAG-279). Photo: National Science Foundation.

icebreaker they should construct for service in the waters of their Archipelago. Although they had decided to construct such a ship, no research on icebreakers was carried out in Canada at the time and the government was dependent on outside sources of information. ${ }^{99}$ From Task Force 80 they found that Eastwind and Edisto rolled badly in open waters, caused by fine bows that fell into the trough of the sea, while their much fuller stern rose. With insufficient body and buoyancy to lift the bow quickly enough, the ship cut into the next sea below, which caused a great deal of water to crash onto the foredeck, occasionally damaging the deck plates. In the ice the bow created a small wave, a distinct disadvantage in icebreaking operations. All of this indicated that a fuller form at the water line forward, with higher and flared bulwarks, would be advantageous in ice and would keep the ship dryer in a seaway. ${ }^{100}$ The American icebreakers also caused floating ice to form up in their wake during ramming operations, a clear indication that the stern sections required modification to push floating ice out of the wake. Finally, the Canadians learned that the speed of the propellers had to be controlled to prevent

99 Minutes of the 2/49 Meeting of the Arctic Research Advisory Committee, 28 March 1949, LAC, RG 24, box 9, file S-1200-A1, pt.1.

100 Captain F.A. Germain to J.C. Lessard, 29 April 1949, LAC, RG 25, vol. 5737, file 17-E (s). 
damage when the blades struck ice blocks. ${ }^{101}$ The best possible icebreakers would have a strong hull structure, sturdy side plating, power and propellers well down in the water.

In the end, Task Force 80 generated extensive knowledge about a relatively unknown region. The Canadian Chiefs of Staff Committee agreed in December that the U.S. should be encouraged to carry out similar cruises in northern waters - with Canadian observers and full disclosure of research findings to the Canadian government - to improve awareness of areas that Canadians could not reach on their own. At the meeting, Escott Reid emphasized that all proposals for the movement of U.S. ships in Canadian waters should be as specific as possible to avoid any possible "misunderstandings." He also recommended that Canadians attain more information on what training would be done, what material would be tested, and all observations made during the cruise. Furthermore, Canadian agencies with interests in the region should be given the opportunity to submit study requests when subsequent naval missions were being planned. The Chiefs of Staff Committee agreed, ${ }^{102}$ and all of these actions ensured better Canadian control of the situation in the Arctic.

Subsequent U.S. naval operations in the Canadian Arctic revealed how much both Canadian and American authorities learned from the cruise of Task Force 80. In early December 1948, for instance, the USN sought permission for Edisto to operate in the waters off Baffin, Devon and Bylot Islands that winter. Now that the Americans had a clearer understanding of Canadian sensitivities, they made a point of asking for permission to enter Canadian territorial waters, invited the Canadians to send observers, promised to provide Canada with copies of all reports made on the voyage, and obtained all of the proper permits and licences. The Canadians pressed the Americans for a complete list of all the projects they wished to undertake, all the aircraft involved, any additional investigations contemplated, and the training they hoped to complete. ${ }^{103}$ They also ensured that the Americans supplied a detailed operations plan, complete with the route the ship would take. ${ }^{104}$ Both countries had learned from the mistakes of the previous summer.

Publicity remained an ongoing irritant, with leaks about Edisto's winter cruise and the summer resupply mission of 1949 appearing in the press. There were simply too many people involved in the operations to ensure complete secrecy. The Canadians,

101 Memorandum, R. Baker, Constructor Captain, Naval Construction Chief, 13 May 1949, LAC, RG 24, vol.9, file S-1200-A1, pt.2.

102 Minutes of the $437^{\text {th }}$ Meeting, Chiefs of Staff Committee, 7 December 1948, R.L. Raymont Collection, DHH 73-1223, series 3, file 1307.

103 Memorandum from Acting Head of Defence Liaison Division to Acting USSEA, 3 December 1948, LAC, RG 85, vol. 2083, file 7140-3. Specifically, the purposes of the project were: investigating ice conditions and practicability of operations in the area under winter conditions, operational limitations of Arctic type vessels, testing the practicability of unloading cargo over the ice, training personnel and test equipment, recording ice conditions, observing geographic, navigational and aviation conditions, and recording hydrographical, meteorological and electromagnetic propagation data. The Canadians asked explicitly if the training would include any firing practice, munitions or military exercises.

104 Memorandum by Department of External Affairs, 11 January 1949, DCER, vol. 15, 1949, ed. Hector Mackenzie (Ottawa, 1995), 1496-1498. 
however, continued to push the Americans to deal with the publicity on defence projects more discreetly. They reminded the State Department and the Department of Defense about the need for closer consultation on publicity and the difficulties created by arrangements made with the press without Canadian knowledge. George Magann suggested issuing a press release at the beginning of new expeditions, otherwise both governments would be swamped with numerous media inquiries. ${ }^{105}$ Before Edisto's winter cruise in 1949, however, the Americans hesitated and the voyage left for the Arctic with no publicity. The matter came to a head when a helicopter attached to the icebreaker crashed, killing its pilot, and the Americans were swamped with media inquiries. Magann "took advantage of the occasion to point out to the State Department that had the United States authorities reached a decision earlier about a press release they would not be in their present embarrassing position." ${ }^{106}$ The Canadians hoped that the incident would force the Americans to make quicker decisions about publicity in ensuing missions. Mistakes, however, continued to occur.

While the publicity problems surrounding Edisto's winter cruise were bothersome, the voyage remained an overall success. It gathered new information, reporters consulted the Canadians before they released their stories, and the Americans extended the Canadian observers every possible courtesy. Captain F.A. Germain noted that "the cordial relations between the Officers of the ship and the Canadian party established on the first day of joining, continued throughout the voyage. Every effort was made for the comfort and convenience of the party insofar as the facilities of the ship would permit, and the fullest co-operation was received to carry out the duties of observers." ${ }^{107}$ The success of the operation and the Canadian participation encouraged Canadian officials planning for subsequent supply missions.

Relations between the observers and the Americans also ran so smoothly because of additional training given to Canadians. The observers on Edisto understood their roles and expectations. Before the 1949 summer resupply mission the observers went through an intensive three-day instruction course where they listened to specialists on topics ranging from the Northwest Territories, to sovereignty, tides and currents, ice, geology and the RCMP. ${ }^{108}$ This training prepared them to deal with any violations of Canadian ordinances that might occur. Hugh Keenleyside, the commissioner of the NWT, gave the closing address to the observers at the end of the training and remarked:

As you know, Sovereignty over the Canadian Arctic carries with it duties and obligations. We must make our administration of the area active and complete. This not only involves vigorous administration and supervision of all activities carried on in the area but it also means a continuous, close study of the territory from every

105 Magann to Snow, 21 January 1949, LAC, RG 25, vol. 5737, file 17 E(s).

106 Canadian Ambassador to SSEA, 24 February 1949, ibid.

107 Captain F.A Germain, Leader of Canadian Group on Edisto, 4 April 1949, ibid.

108 Briefing: Canadian Observers, accompanying the Arctic Weather Station Re-Supply Mission, Summer 1949, 27 June 1949, LAC, RG 85, vol. 302, file 1009-5-1; R.A. Gibson to Mr. Gaskell, 8 August 1949, LAC, RG 85, vol. 2083, file 7140-C. 
aspect likely to lead to its greater development or usefulness. Your activities, of course, being primarily devoted to scientific observation and investigation, would come under the second category. Your aim, in brief, is to extend our field of scientific knowledge. ${ }^{109}$

The government also expanded the role of the observers for the summer supply mission. The Northwest Territories Administration informed J.W. Burton, the deputy director of military intelligence during the war, that as the senior observer he needed to "ensure that while travelling within the Canadian Arctic Sector and its territorial waters adjacent thereto, that Canada's sovereignty is respected and her laws and ordinances are enforced. Further, you will ensure that Canada's prestige is maintained in every respect during the entire Mission." To perform these roles, Burton was made into a game officer, a notary public, a coroner, and given the authority to issue licenses to scientists, explorers, archaeologists and ethnologists. The government also clearly defined its expectations for the other observers. They would examine sites for the establishment of ground control fixations, engage in geological reconnaissance of coal deposits on Ellesmere and Melville Islands, and conduct biological, hydrographical, topographical, geological, geographical and wild life land reconnaissance studies, particularly of those areas close to stations and those areas of strategic and economic importance. They would also study icebreaker designs and operation, seek out future RCMP detachment sites, and investigate ice, navigation, living and working conditions. ${ }^{110}$ The observers' role was to assist Canada in learning about its Arctic, an essential element in establishing control. Having learned their lessons from Task Force 80 and provided explicit instructions, the 1949 sea supply mission was a success with no perceived infractions against Canada's sovereignty.

While Task Force 80 pushed the Canadian government to tighten its control of subsequent Arctic defence projects, officials remained fixated on symbolic displays of sovereignty and presence in the region. Largely in response to Task Force 80, the RCN decided to send a small task force to Hudson Bay in September 1948. The military ran a four day publicity campaign trumpeting the success of the mission, even though the waters it traversed were neither challenging nor in areas where Canada's sovereignty was contested. "The ships were simply following an established shipping route that had been in existence for three centuries and which had been marked with modern aids to navigation for twenty years," historian Kenneth Eyre astutely observed. ${ }^{111}$ The ships did not ferry supplies to any of the weather stations or airstrips in the High Arctic — their activities were purely symbolic. Nevertheless, the navy trumpeted this visual display of Canada's authority in the North and its interest in improving naval capabilities. In the end, Task Force 80 was a major factor pushing Ottawa to implement its broader "Canadianization" programme for the Arctic in 1949, including acquiring a Canadian

109 Notes for Dr. Keenleyside's Closing Address, Canadian Observers, Accompanying the Arctic Weather Station Re-Supply Mission, Summer, 1949, ibid.

110 R.A. Gibson to J.W. Burton, 29 June 1950, LAC, RG 85, vol. 303, file 1009-5, pt.1a.

111 Kenneth C. Eyre, "Custos Borealis: The Military in the Canadian North" (unpublished Ph.D. thesis, University of London-King's College, 1981). 
icebreaker. ${ }^{112}$ The Wind-class icebreaker HMCS Labrador did not come into RCN service until July $1954,{ }^{113}$ but it was a reflection of Canada's early postwar experiences - and the search for an adequate level of functional control over activities in its Arctic waters.

The story of Task Force 80 highlights several key elements of the Canadian government's strategy in the North during the early Cold War. First, it reveals the sustained concern in Ottawa that Canada's sovereignty in the Arctic was tenuous and, too use Hume Wrong's apt phrase: "unchallenged, but not unchallengeable." 114 Canada depended upon the United States for the naval resupply of installations in its Arctic dedicated to continental defence, and it struggled to retain practical control over activities in its waters. The bilateral friction that accompanied naval activities was not a product of a grand conspiracy by the Americans wilfully opposing Canadian sovereignty. Instead, it was a reflection of low-level indiscretions and poor communications on both the Canadian and American sides. While some historians have emphasized the conflict, they have been less observant of the most important outcome: lessons were learned and solutions worked out, which allowed Canada to professionalize its approach to Arctic operations and encouraged, in due course, investments in its own capability tools.

When the United States embarked upon the construction of the Distant Early Warning (DEW) Line in the mid-1950s, patterns of relationships were already set that ensured the shipment of thousands of tonnes of materiel to isolated stretches of Arctic coastline was completed cooperatively. "The assault plan is as complicated as a largescale military invasion," journalist Leslie Roberts informed readers of Harper's Magazine in August 1955. "It calls for approaches on two fronts, an eastern and a western $\ldots$ for interlocking movements by air, river, and sea ... for the use of helicopters, Flying Boxcars, snow trains, icebreakers, landing craft, and dog teams ... for the intimate cooperation of military men, civilian construction workers, explorers, and sourdoughs of two nations." 115 American capabilities proved essential to construct and support continental defences in the far north; and, once again, Canadians exercised control over Arctic operations because their American ally was willing to accommodate their concerns and interests.

112 Minutes of the $7^{\text {th }}$ Meeting of the Transportation Sub-committee of the Advisory Committee on Northern Development, 3 December 1948, LAC, RG 2, vol. 57, file A-25-5-T. For a recent survey of the RCN's development of Arctic expertise in the early Cold War, see Richard Mayne, “'An Art of Its Own”: Corporate Knowledge, the Canadian Navy and Arctic Operations," Canadian Naval Review V, no.3 (Fall 2009), 10-16.

113 On the history of HMCS Labrador, see John Leeming, "HMCS Labrador and the Canadian Arctic," in RCN in Retrospect, ed. James Boutilier (Vancouver, 1982), 286-307.

114 Hume Wrong to A.D.P. Heeney, 24 June 1946, LAC, RG 25, vol. 3347, file 9061-A-40, pt.1.

115 Leslie Roberts, “The Great Assault on the Arctic," Harper's CCXI, no.1263 (1955), 37-42. 